of Botany a collection of 23,000 microscope slides of diatoms, together with catalogues, books and pamphlets, and the microscope with which he worked. For many years past Mr. Adams acquired whatever diatom collections came on the market, and thus accumulated the largest collection in private hands.

\section{British Museum Excavations in Northern Syria}

Some further details of finds of the British Museum archæological expeditions to northern Syria under Sir Leonard Woolley and Mr. M. E. L. Mallowan in 1938 are given in the official summaries (Brit. Museum Quarterly, 13, 1; 1939). The most important objects found within the palace at Atchana, in the opinion of Sir Leonard Woolley, are the clay tablets inscribed in cuneiform in the Akkadian language, from which it has been possible to learm not only the name of the place-Alalakh-but also the names of several of its rulers. One of these was contemporary with Saushsatar, a king of Mitanni, already known as a leading potentate in western Asia in the middle of the fifteenth century B.c. Among the small objects the most interesting is a steatite roundel engraved on both surfaces with formal patterns surrounding a middle ring, which encloses characters of the Hittite hieroglyphic writing. At Tall Brak Mr. Mallowan found the great palace to be a building of Naram Sin of Agade, bricks being stamped with his name, and tablets being found of the Agade period of about 2500 B.c. The south-west corner of the palace proved to be built over the ruins of a great mud-brick tower, probably part of a temple, belonging to the Jemdet Nasr period, more than five hundred years earlier. It rested on a clay platform, under which was buried a great number of votive objects. Most of them were in underground chambers, which had been visited by robbers in antiquity. Apart from a large collection of beads, there were many amulets of two principal kinds, the first being stamp seals in the form of animals, or animal heads, and secondly little stone 'idols' found in large numbers, which though classed as amulets, are of unknown significance. They vary little in style; but some show as many as three pairs of eyes side by side, while one or two seem to portray mother and child. Many sherds of prehistoric painted ware were found, especially of the Tell Halaf style.

\section{Recent Earthquakes}

AN earthquake giving rise to large amplitudes on seismograms is reported by European observatories to have taken place on April 18, the initial waves being received about $6 \mathrm{~h} .36 \mathrm{~m}$. G.C.T. and the tremors lasting about three hours. The shock was well recorded at Stonyhurst, near Blackburn; at Kew, where it was received at $36 \mathrm{~m} .22 \mathrm{~s}$; ; at Uccle, where it was received at $36 \mathrm{~m}$. $31 \mathrm{~s}$.; and at Zurich, where it was received at $36 \mathrm{~m}$. $18 \mathrm{~s}$. A very prominent feature of the seismograms at the latter three observatories was the $S_{c} P_{c} S$ or $S K S$ wave, which is a pulse starting at the epicentre as a transverse wave, being transformed at the earth's core to a longitudinal wave, continuing thus to the other side of the core where it is again changed back to a transverse wave. It is received as a transverse wave at the observatory. The epicentral distance of the shock from Ucele is calculated from the arrival times of the various pulses to be approximately $105^{\circ}$, which is consonant with an epicentre in Chile, though the azimuth has been difficult to determine, and confirmation or otherwise is awaited from the American observatories.

Two earth tremors are reported from Barbados to have been felt about 1.45 p.m. on April 20. At St. Kitts, several shocks were felt, though no damage is reported from the vicinity of either area. Tremors in the West Indies are by no means uncommon, and it will be recalled that the earthquake swarm which occurred in 1934 and 1935 in Montserrat led to the dispatch of an expodition to that island, and to consequent valuable reports by Mr. A. G. Macgregor and Dr. C. F. Powell. In September 1938 the Wiechert seismograph and eight Jagger shock recorders set up at the time of the expedition were still in operation on the island under the care of Mr. Kelsick. Then from August until November 1937 about forty shocks were reported from Dominica. The Royal Society afterwards nominated a West Indies Seismological Committee, which contemplated sending an expedition to this latter island. The shocks, however, diminished in frequency, and it is now wondered whether or not the centre of seismic activity in the islands has again changed.

\section{Long-Distance Automatic Telephony}

As improvements were made in manually operated switchboards, the trend of telephony has always been to substitute automatic devices for human labour. So much progress was made in this direction that it soon became obvious that even in large cities it would be possible to eliminate almost all the operators by the substitution of electrically controlled machinery. In the Revre Génerale de l'Electricite of March 11, M. R. Dreyfus discusses the prospects of long-distance automatic telephony and points out that in small countries like Switzerland and Holland automatic inter-urban working is already in process of realization. It has now been developed to the extent of eliminating the operator at the exchange of the subscriber initiating a trunk call. By simply using his dial the subscriber puts himself in touch with any other subscriber in the same country. $M$. Dreyfus thinks it quite likely that automatic operation will now be developed for international calls. The International Consulting Committee for Long Distance Telephone Communication (the C.C.I.T.), which was formed by international delegates at a conference in Paris in 1923, has now taken up the problem. It is stated that within a few years a subscriber in Paris will be able merely by dialling to put himself through to a subscriber in Now York.

\section{Factory Lighting}

THe spinning and twisting of real silk threads for the hosiery and silk weaving trade involves the processing of threads as small as two-thousandths of an 